\title{
Enterohepatic circulation of sulphur in female goats
}

\author{
BY CHRISTINE HALAIS* AND R. J. MOIR \\ Department of Animal Science, School of Agriculture, University of Western Australia, \\ WA 6009, Australia
}

(Received 22 February 1989 - Accepted 5 October 1989)

\begin{abstract}
Sulphur flow through the gut was monitored in eight adult female goats at different stages in their reproductive cycle. The amount of $S$ transferred from the body into digesta between the mouth and the transverse duodenum was directly proportional to the amount of nitrogen retained in the body and secreted in milk. S secretion into digesta was also a function of metabolic body-weight (body-weight ${ }^{075}$ ) in non-pregnant, non-lactating goats and in pregnant goats. During lactation there was an additional $S$ input into digesta, and $S$ gain was directly proportional to the yield of milk $N$. The $S$ was conserved by intestinal absorption and was recycled to the gut predominantly as carbon-bound (neutral) $\mathrm{S}$ in bile. The enterohepatic circulation may act as a mobile reserve of $S$, particularly of taurine.
\end{abstract}

Enterohepatic circulation: Sulphur: Goat

Sulphur is transferred from the body to the gut in the form of sulphates (Bray, 1969) and bile salts (Sobotka, 1937), which are both end-products of protein metabolism, as well as in digestive enzymes. The rate of transfer of endogenous $S$ to the gut has not been studied extensively, although the concentration of inorganic sulphate in blood serum (Kennedy \& Milligan, 1978) and the amount of fermentable substrate in the hind-gut (Bird \& Thornton, 1972) are known to influence this transfer. In contrast, renal excretion of neutral S has long been associated with protein turnover in the animal (Folin, 1905). Amann (1983) observed that the rate of urinary neutral $\mathrm{S}$ excretion per unit body-weight varied little within animal species, and concluded that this excretion was directly proportional to the energy expenditure of the animal. Brody et al. (1934) compiled results on neutral S excretion in urine over a wide range of animal species; the excretion of neutral $\mathrm{S}$ increased by 6.85 $\mathrm{mg}$ /animal per $\mathrm{d}$ per unit increase in metabolic body-weight ( $\mathrm{kg}$ body-weight $(\mathrm{BW})^{0.84}$ ). Protein turnover per unit metabolic weight $\left(\mathrm{BW}^{0.75}\right)$ was found to be similar in several species of mammals (Reeds \& Lobley, 1980). Thus, neutral S excretion in urine is directly related to the rate of protein turnover in the animal. A similar relationship may hold with respect to the rate of transfer of $S$ into the gut since the $S$ compounds involved are principally end-products of protein metabolism. Changes in the types of protein being synthesized by the animal, such as occur in pregnancy and in lactation, compared with the non-pregnant, non-lactating state, may influence this relationship. The present paper attempts to quantify the enterohepatic circulation of $S$ in female goats, and relates the flow of endogenous $S$ through the duodenum to indices of nitrogen metabolism in these animals at different stages in their reproductive cycle.

\section{METHODS}

Animals and diets

We selected for this experiment eight adult female goats of feral stock from the arid shrublands of Western Australia. They were cannulated at the rumen and at the transverse

* Present address: PO Box 882, Beenleigh, Queensland 4207, Australia 
Table 1. Experimental structure

\begin{tabular}{llllllll}
\hline \hline & $\begin{array}{llllll}\text { Period... } \\
\text { Goat no. }\end{array}$ & 1 & 2 & 3 & 4 & 5 \\
\hline 1 & P & L & O & O & O \\
2 & O & O & O & O & $*$ \\
3 & O & O & O & P & L \\
4 & P & L & O & O & O \\
5 & O & O & O & O & I \\
6 & P & L & O & O & O \\
7 & O & O & O & $*$ & $\mathrm{~L}$ \\
8 & P & L & O & O & O \\
\hline
\end{tabular}

$P$, pregnant; L, lactating; $I$, lactation induced by hormonal injections; $O$, non-pregnant, non-lactating.

* Animal died.

duodenum immediately caudal to the sigmoid loop, and posterior to the entry of the common bile and pancreatic duct. The animals were confined to metabolism crates throughout the experiment and fed on a ration of chopped oaten hay, lupin (Lupinus angustifolius) seeds, and a mineral supplement. This diet contained $17.5 \mathrm{~g} \mathrm{~N}$ and $1.5 \mathrm{~g} \mathrm{~S} / \mathrm{kg}$ dry matter, and was offered at a rate of 1.2 times the previous day's intake, in equal portions, at two-hourly intervals.

\section{Experimental design}

The experiment was carried out over 2 years; in the first year half the goats were inseminated, gave birth, and subsequently lactated. The following year the treatments were reversed. Experimental variables were monitored 2 weeks before insemination and at 6 weeks pre- and post-partum (periods 1 to 5). Two goats died during the monitoring period but only one could be replaced. The remaining seven goats were killed for post-mortem analysis to establish the probable source of $S$ in duodenal digesta (period 6).

\section{Monitoring of experimental variables}

Periods 1 to 5. The $\mathrm{S}$ intake and faecal output of each animal were measured daily during a 1-week $\mathrm{N}$ balance trial; the goats were weighed at the beginning and the end of the trial. The flow of digesta at the duodenum was monitored on three alternate days of the preceding week, using ${ }^{51} \mathrm{Cr}$-EDTA and ${ }^{103} \mathrm{Ru}$-phenanthroline, in a dual-phase marker technique (Faichney, 1975). Sodium sulphate labelled with ${ }^{35} \mathrm{~S}$ was infused simultaneously with the digesta markers into the rumen, and recovered in samples of duodenal digesta.

Period 6. Goats were managed as in previous periods, excluding infusions of radioisotopes. A sample of duodenal digesta was collected from each goat before slaughter. At necropsy, samples of digesta from reticulo-rumen, omasum and abomasum, and of bile from the gall bladder, were also collected from chemical analysis.

Total S (TS), neutral S (nS) and ${ }^{35} \mathrm{~S}$ were determined by the method of Bird \& Fountain (1970). Levels of TS in representative samples of food, faeces and duodenal digesta were confirmed by X-ray fluorescence spectroscopy (Reed, 1973). N was determined by the Kjeldahl method (Association of Official Analytical Chemists, 1980).

\section{Statistical analysis}

The experimental structure achieved is summarized in Table 1. The original cross-over design of the experiment was not pursued due to animal failures in periods 4 and 5 . Instead the periods were ignored and measurements made in periods 1 to 5 regarded as replicates 
on each goat at different stages of reproduction (pregnancy, lactation and the nonpregnant, non-lactating state).

The relationship between variables was investigated by linear regression analyses (Sokal \& Rohlf, $1981 a$ ). In these analyses the following model was assumed best to describe the relationship between variables:

$$
\begin{aligned}
& \text { response }=\text { goat effect }+ \text { stage of reproduction effect }+(\text { stage of reproduction } \\
& \text { effect } \times \text { explanatory variable })+ \text { error. }
\end{aligned}
$$

This was abbreviated to

$$
\text { response }=G+R+(R \times \text { explanatory })+\text { error, }
$$

where $G$ is a factor for each of the eight goats and differs with every relationship and $R$ is a factor for each of the three stages of reproduction.

The following sub-models were derived from the basic model 1:

$$
\begin{aligned}
& \text { response }=G+R+\text { error, } \\
& \text { response }=R+(R \times \text { explanatory })+\text { error } \\
& \text { response }=R+\text { explanatory }+ \text { error, }
\end{aligned}
$$

(and further sub-models, as appropriate).

For each of these equations, the mean of squares is a measure of the variation between the observed response and the response estimated from the equation. The mean of squares derived from one model was tested against that derived from other models using $F$-ratios (from analysis of variance); the simplest model adequately describing the relationship was selected. Differences between regression of coefficients and between means were tested for significance using Student's $t$ test (Sokal \& Rohlf, $1981 b$ ). Differences with a $P \leqslant 0.05$ were accepted as significant.

An exploratory investigation attempting to implement the original cross-over design using missing values indicated that similar conclusions would ensue but that it fails to utilize all values. In another preliminary investigation, analysis of covariance models were applied to values from goats nos. 1, 3, 4,6 and 8 (those with an observation in pregnancy and one in lactation as well as three observations when non-pregnant, non-lactating). The results obtained were qualitatively all the same as those of the linear regression analyses; however, the covariance models examined within-goat relationships and did not allow for different slopes for the covariates in the pregnant, lactating and non-pregnant, nonlactating states. Such differences could not be ignored since the linear regression analyses indicated these to be of significance in some of the relationships examined.

In the linear regression models utilized, periods were ignored; these may have had an effect, through season or age of the animal, on the goat responses, although the goats were mature animals in a stabilized environment. An exploratory analysis indicated that when the periods were added to the linear regression models they were marginally significant, but that they tended to be confounded with pregnancy and lactational effects. Period effects may have masked differences that existed between pregnant, lactating and non-pregnant, non-lactating goats. Where such differences were indicated by linear regression analyses, they are upheld in the Discussion by reference to experimental evidence obtained by other workers.

\section{RESULTS}

$\mathrm{S}$ balances in the gut of female goats at different stages of reproduction showed that endogenous S flows into digesta, between the mouth and the duodenal cannula, were five 
Table 2. Sulphur flows in female goats at different stages in the reproductive cycle (Mean values and standard deviations)

\begin{tabular}{|c|c|c|c|c|}
\hline \multirow[b]{2}{*}{ No. of replicates... } & \multicolumn{4}{|c|}{ Stage of reproduction } \\
\hline & & $\begin{array}{l}\text { Non-pregnant, } \\
\text { non-lactating } \\
26\end{array}$ & $\begin{array}{l}\text { Pregnant } \\
5\end{array}$ & $\begin{array}{c}\text { Lactating } \\
7\end{array}$ \\
\hline$S$ intake (g/goat per d) & $\begin{array}{l}\text { Mean } \\
\text { SD }\end{array}$ & $\begin{array}{l}0.78^{\mathrm{a}} \\
0.25\end{array}$ & $\begin{array}{l}1 \cdot 16^{\mathrm{b}} \\
0 \cdot 20\end{array}$ & $\begin{array}{l}1 \cdot 14^{b} \\
0 \cdot 34\end{array}$ \\
\hline \multirow{4}{*}{$\begin{array}{l}\text { Flow of } S \text { at duodenum } \\
\text { (g/goat per } d) \\
\text { Faecal } S \text { output (g/goat per } d)\end{array}$} & Mean & $4 \cdot 50^{\mathrm{a}}$ & $8 \cdot 41^{b}$ & $8 \cdot 24^{\mathrm{b}}$ \\
\hline & SD & 1.73 & 3.49 & 2.95 \\
\hline & Mean & $0.36^{\mathrm{a}}$ & $0.63^{\mathrm{b}}$ & $0.54^{\mathrm{b}}$ \\
\hline & SD & $0 \cdot 10$ & 0.17 & 0.13 \\
\hline \multirow{2}{*}{$\frac{\text { Flow } n S \text { at duodenum }}{\text { Flow } S \text { at duodenum }}$} & Mean & 0.985 & 0.986 & 0.988 \\
\hline & SD & 0.008 & $0 \cdot 006$ & 0.005 \\
\hline \multirow{2}{*}{$\frac{\text { Flow }{ }^{35} \mathrm{~S} \text { at duodenum }}{\text { Dose }{ }^{35} \mathrm{~S} \text { into rumen }}$} & Mean & $1.37^{\mathrm{a}}$ & $1 \cdot 67^{\text {ab }}$ & $1 \cdot 85^{b}$ \\
\hline & & & & \\
\hline \multirow{2}{*}{$\frac{\mathrm{N}_{\text {GAIN }} \text { in digesta }}{\mathrm{S}_{\text {GAIN }} \text { in digesta }}$} & Mean & $1 \cdot 34$ & 0.95 & 0.90 \\
\hline & $\mathrm{SD}$ & 0.84 & $0 \cdot 30$ & 0.58 \\
\hline \multirow{2}{*}{$\frac{\mathrm{S}_{\mathrm{GAIN}} \text { in digesta* }}{\mathrm{BW}^{0.75}}$} & Mean & $0 \cdot 227^{\mathrm{a}}$ & $0.356^{\mathrm{ab}}$ & $0.436^{\mathrm{b}}$ \\
\hline & SD & $0 \cdot 120$ & $0 \cdot 129$ & 0.145 \\
\hline
\end{tabular}

a,b Means in the same row with unlike superscript letters were significantly different $(P \leqslant 0.05)$.

$\mathrm{nS}$, neutral $\mathrm{S} ; \mathrm{N}_{\mathrm{GAIN}}$, nitrogen transferred from the body into digesta; $\mathrm{S}_{\mathrm{GAIN}}, \mathrm{S}$ transferred from the body into digesta between mouth and cannula; $\mathrm{BW}^{0.75}$, body-weight $\mathrm{t}^{0.75}$.

${ }^{*} \mathrm{~g} / \mathrm{kg} \mathrm{BW}{ }^{0.75}$ per d.

to six times higher than $\mathrm{S}$ intakes, and that these inputs were largely reabsorbed into the body (Table 2).

Extensive recycling of $S$ through the gut was confirmed by radioisotope tracer studies in these animals. The flow of ${ }^{35} \mathrm{~S}$ at the duodenum was higher than the dose of ${ }^{35} \mathrm{~S}$ infused into the rumen over all goats in periods 1 to 5 (Table 3). Further analysis of the values for ${ }^{35} \mathrm{~S}$ flows, allowing for differences between goats and periods, showed that the mean for day 8 was greater than for day $6(P \leqslant 0.05)$ or for day $4(P \leqslant 0.01)$ as a result of progressive enrichment of duodenal digesta with ${ }^{35} \mathrm{~S}$. In lactating goats the mean flow of ${ }^{35} \mathrm{~S}$ at the duodenum in proportion to the dose infused into the rumen was higher than in nonpregnant, non-lactating goats $(P \leqslant 0.01)$, indicating a higher input of $S$ into digesta in these goats (Table 2).

From analyses of digesta and bile collected at post-mortem examination it is evident that a major input of $\mathrm{S}$ and $\mathrm{N}$ occurred between the abomasum and the duodenal cannula, and that this input included contributions from bile (Fig. 1).

The amount of $S$ transferred from the body into digesta between the mouth and the duodenal cannula $\left(\mathrm{S}_{\mathrm{GAIN}}\right)$ was calculated as TS flow at the duodenum minus TS intake, and averaged over $3 \mathrm{~d}$ in each of periods 1 to $5 . \mathrm{S}_{\mathrm{GAIN}}$ also included $0 \cdot 1 \mathrm{~g} \mathrm{Na}_{2} \mathrm{SO}_{4} / \mathrm{d}$ infused into the rumen of each goat over this period. $\mathrm{N}$ transferred from the body into digesta $\left(\mathrm{N}_{\text {GAIN }}\right)$ was calculated similarly from $\mathrm{N}$ flows at the duodenum and $\mathrm{N}$ intakes. Linear regression analyses indicated a high positive relationship between $\mathrm{S}_{\mathrm{GAIN}}$ and $\mathrm{N}_{\mathrm{GAIN}}$ when all goats were considered together $(P \leqslant 0 \cdot 01)$ but this relationship differed with stage of reproduction $(P \leqslant 0.05)$. 
Table 3. Flow of ${ }^{35} S$ at the duodenum as a multiple of the dose of ${ }^{35} S$ infused into the rumen of all goats in periods 1 to $5^{*}$

(Mean values with their standard errors)

\begin{tabular}{ccccc}
\hline Day of infusion & Meant & SE & $n$ \\
\hline & 4 & 1.46 & 0.088 & 35 \\
6 & 1.48 & 0.084 & 38 \\
& 8 & 1.54 & 0.085 & 34 \\
\hline
\end{tabular}

* For details, see p. 240.

$\dagger$ The means for each day were significantly greater than $1(P \leqslant 0.001)$.

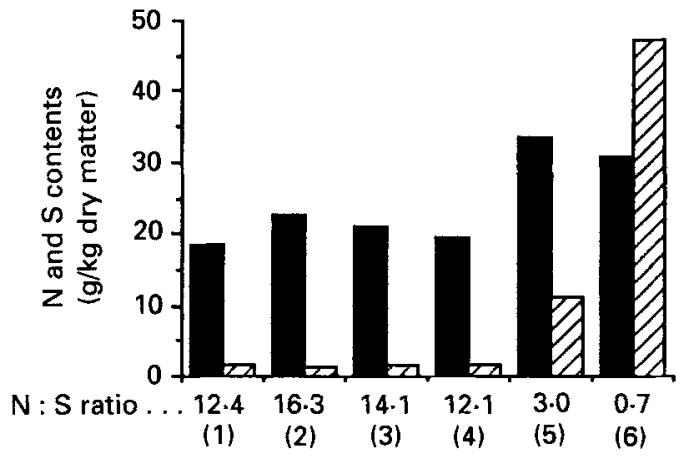

Fig. 1. Mean nitrogen ( $\square$ ) and sulphur (䍘) contents of food, digesta and bile of female goats in period 6 (for details see p. 240). (1), Food eaten; (2), rumen digesta ; (3), omasal digesta; (4), abomasal digesta; (5), duodenal digesta; (6), bile from gall bladder.

At all stages of reproduction, $\mathrm{S}_{\mathrm{GAIN}}$ was a function of the amount of $\mathrm{N}$ retained in the body and secreted in milk (NRM; g/goat per d) (see Table 4). The relationship between $\mathrm{S}_{\mathrm{GAIN}}$ and NRM is analysed in Table 5 . The $F$-ratio for comparing model 2 to model 1 was derived as follows:

$$
\left[\left(\mathrm{SS}_{2}-\mathrm{SS}_{1}\right) \div\left(\mathrm{df}_{2}-\mathrm{df}_{1}\right)\right] \div \mathrm{MS}_{1}
$$

where SS is sums of squares, $\mathrm{df}$ is degrees of freedom and MS is mean of squares. The level of significance of the $F$-ratio was derived from tables of critical values of the $F$ distribution using $\mathrm{df}_{2}$ minus $\mathrm{df}_{1}$ for the numerator, and $\mathrm{df}_{1}$ for the denominator. This procedure has been followed in all subsequent comparisons of models to model 1.

The $F$-tests from Table 5 show that there was a highly significant linear regression relationship of $\mathrm{S}_{\text {GAIN }} v$. NRM (model $2 v$. model 1 ). A comparison of model 3 against model 1 indicates that the constants for each goat $\left(G_{1}\right)$ cannot be eliminated. There were no differences within goats at different stages of reproduction in either regression coefficients (model $4 v$. model 1 ) or intercept in the regression equation (model $5 v$. model 1). Model 5 is thus the simplest adequate model to describe this relationship. The estimated regression equation based on this model is:

$$
\mathrm{S}_{\text {GAIN }}=G_{1}+0.78(\text { SE 0.66) }+0.67(\text { SE 0.09) NRM. }
$$

The constants in the equation relate to obligate transfers of $\mathrm{S}$ from the body to the gut, between the mouth and the duodenal cannula. These $S$ transfers are $0.78 \mathrm{~g} \mathrm{~S} / \mathrm{d}$ for each goat, plus $G_{1}$, an amount that differs between goats. 
Table 4. Nitrogen balances and body-weights of female goats at different stages in the reproductive cycle

(Mean values and standard deviations)

\begin{tabular}{|c|c|c|c|c|}
\hline \multirow[b]{2}{*}{ No. of replicates... } & \multicolumn{4}{|c|}{ Stage of reproduction } \\
\hline & & $\begin{array}{c}\text { Non-pregnant, } \\
\text { non-lactating } \\
26\end{array}$ & $\begin{array}{c}\text { Pregnant } \\
5\end{array}$ & $\begin{array}{c}\text { Lactating } \\
7\end{array}$ \\
\hline \multirow{6}{*}{$\begin{array}{l}\mathrm{N} \text { retained including } \\
\text { milk } \mathrm{N} \text { (g/goat per } \mathrm{d}) \\
\mathrm{N} \text { secreted in milk } \\
(\mathrm{g} / \text { goat per } \mathrm{d}) \\
\text { Body-wt }(\mathrm{kg})\end{array}$} & Mean & $2 \cdot 7^{\mathrm{a}}$ & $7 \cdot 0^{\mathrm{b}}$ & $6 \cdot 7^{b}$ \\
\hline & SD & 1.53 & $3 \cdot 00$ & $3 \cdot 10$ \\
\hline & Mean & $\mathrm{Nil}$ & $\mathrm{Nil}$ & 3.9 \\
\hline & $\mathrm{SD}$ & & & $1 \cdot 88$ \\
\hline & Mean & $42 \cdot 8^{\mathrm{a}}$ & $52 \cdot 8^{\mathrm{b}}$ & $39 \cdot 2^{\mathrm{a}}$ \\
\hline & SD & $5 \cdot 0$ & $6 \cdot 5$ & $3 \cdot 5$ \\
\hline \multirow{2}{*}{$\begin{array}{l}\text { Change in body-wt } \\
\text { during } N \text { balance trial } \\
\text { (kg/goat per week) }\end{array}$} & Mean & $+0 \cdot 1$ & +0.9 & $-0 \cdot 4$ \\
\hline & $\mathrm{SD}$ & $0-9$ & $1 \cdot 4$ & 0.5 \\
\hline
\end{tabular}

a,b Means in the same row with unlike superscript letters were significantly different $(P \leqslant 0 \cdot 05)$.

Table 5. Comparison of models for the relationship sulphur gain $v$. nitrogen retained in the body and secreted in milk $(\mathrm{g} / \mathrm{d})$

\begin{tabular}{lcccc}
\hline \hline $\begin{array}{l}\text { Model } \\
\text { no. }\end{array}$ & $\begin{array}{c}\text { Degrees } \\
\text { of freedom }\end{array}$ & $\begin{array}{c}\text { Sums of } \\
\text { squares }\end{array}$ & $\begin{array}{c}\text { Mean of } \\
\text { squares }\end{array}$ & $F$ ratio \\
\cline { 2 - 5 } $1 G_{1}+R+R \times \mathrm{NRM}$ & 25 & $39 \cdot 39$ & $1 \cdot 576$ & \\
$2 G_{1}+R$ & 28 & $79 \cdot 18$ & $2 \cdot 828$ & $8 \cdot 41(P \leqslant 0 \cdot 001)$ \\
$3 R+R \times \mathrm{NRM}$ & 32 & 74.79 & $2 \cdot 337$ & $3 \cdot 21(P \leqslant 0 \cdot 025)$ \\
$4 G_{1}+R+\mathrm{NRM}$ & 27 & 44.94 & 1.665 & $1 \cdot 76(\mathrm{NS})$ \\
$5 G_{1}+$ constant $+\mathrm{NRM}$ & 29 & $49 \cdot 22$ & $1 \cdot 697$ & $\mathrm{I} \cdot 56(\mathrm{NS})$ \\
\hline
\end{tabular}

$G_{1}$, constants for each goat; $R$, stage of reproduction effects; NRM, nitrogen retained in the body and secreted in milk (g/goat per $\mathrm{d})$; NS, not significant.

The relationship between $\mathrm{S}_{\text {GAIN }}$ and $\mathrm{BW}^{0.75}(\mathrm{~kg})$ was analysed by a similar statistical procedure. Part of the variation in $S_{\text {GAIN }}$ can be attributed to differences in $\mathrm{BW}^{\mathbf{7 5}}$, but only in non-pregnant, non-lactating, and in pregnant goats. This relationship is described by the following equations:

for non-pregnant, non-lactating goats:

$$
\mathrm{S}_{\mathrm{GAIN}}=-3 \cdot 2(\mathrm{SE} 3 \cdot 5)+0 \cdot 41(\mathrm{SE} 0 \cdot 21) \mathrm{BW}^{0 \cdot 75},
$$

for pregnant goats:

$$
\mathrm{S}_{\mathrm{GAIN}}=-27 \cdot 6(\mathrm{SE} 8 \cdot 1)+1 \cdot 78(\mathrm{SE} 0 \cdot 41) \mathrm{BW}^{0.75} \text {. }
$$

The regression coefficient for pregnant goats was higher than that for non-pregnant, nonlactating animals $(P \leqslant 0.05)$.

In lactating goats no relationship could be established between $S_{\text {GAIN }}$ and $B W^{0.75}$, but $\mathrm{S}_{\mathrm{GAIN}}$ in proportion to $\mathrm{BW}^{0 \cdot 75}$ was on average nearly twice as high as in non-pregnant, nonlactating goats (Table 2), suggesting an input of $S$ additional to that associated with increases in $\mathrm{BW}^{0.75} . \mathrm{S}_{\mathrm{GAIN}}$ in lactation was directly proportional to the yield of milk $\mathrm{N}$ $(P \leqslant 0.01)$. The estimated regression equation describing the relationship between $\mathrm{S}_{\mathrm{GAIN}}$ 
and milk $\mathrm{N}$ (MN; g/goat per $\mathrm{d}$ ) accounted for $74 \%$ of the total variation in $\mathrm{S}_{\mathrm{GAIN}}$ in lactating goats and was

$$
\mathrm{S}_{\text {GAIN }}=0.30(\mathrm{SE} 1.65)+1.55(\mathrm{SE} 0.36) \mathrm{MN} \text {. }
$$

$\mathrm{S}$ transfers into digesta occurred mainly in the form of $\mathrm{nS}$ (TS minus $\mathrm{SO}_{4}-\mathrm{S}$ ) since this fraction represented $99 \%$ of the total flow of $\mathrm{S}$ at the duodenum of all goats monitored in periods 1 to 5 (Table 2). nS also constituted the same percentage of TS in the samples of digesta and bile collected at post-mortem examination.

The endogenous $\mathbf{S}$ in duodenal digesta was highly digestible as indicated by the linear regression equation relating the amount of $S$ apparently absorbed from the intestines $\left(\mathrm{S}_{\mathrm{ABS}} ; \mathrm{g} /\right.$ goat per $\left.\mathrm{d}\right)$ to the flow of $\mathrm{S}$ at the duodenum $\left(\mathrm{S}_{\mathrm{DUOD}} ; \mathrm{g} /\right.$ goat per $\left.\mathrm{d}\right)$.

$$
\mathrm{S}_{\mathrm{ABS}}=G_{2}-0.28(\mathrm{SE} 0.05)+0.96(\mathrm{SE} 0.006) \mathrm{S}_{\mathrm{DUOD}}
$$

Of the flow of $\mathrm{S}$ at the duodenum $96 \%$ was absorbed in the intestines. The constants in this equation relate to faecal losses of S, which were $0.28 \mathrm{~g} \mathrm{~S} / \mathrm{d}$ for each goat, plus $G_{2}$, an amount that differs between goats. $\mathrm{S}$ was effectively conserved by intestinal absorption at all stages of reproduction.

\section{DISCUSSION}

\section{The flow of endogenous $S$ to the duodenum}

The amount of $\mathbf{S}$ transferred from the body to duodenal digesta $\left(\mathbf{S}_{\mathrm{GAIN}}\right)$ was a function of the amount of $\mathrm{N}$ retained by goats at all stages of reproduction. The rates of total protein synthesis and of basal energy expenditure per unit $\mathrm{BW}^{0.75}$ are steady over several species of mammals (Brody et al. 1934; Reeds \& Lobley, 1980). In our goats, except in lactation, $\mathrm{S}_{\mathrm{GAIN}}$ was also directly proportional to $\mathrm{BW}^{0.75}$ and was thereby related to the rates of both protein and energy metabolism in the body. Increases in $\mathbf{B W}^{0.75}$ were probably associated with the enhancement of biliary S flow rather than of enzyme secretions, which are stimulated directly by increases in dry matter intake. $\mathrm{nS}$ excretion in urine was also calculated to be proportional to metabolic body-weight $\left(\mathrm{BW}^{0.74}\right)$ over a wide range of animal species (Brody et al. 1934). This suggests that similar metabolic processes govern both biliary and urinary $\mathrm{nS}$ flows.

The flow of endogenous $\mathrm{nS}$ at the duodenum varied in the course of reproduction; average $\mathrm{S}_{\mathrm{GAIN}}$ were nearly twice as high per unit $\mathrm{BW}^{0.75}$ in lactating compared with nonpregnant, non-lactating goats; pregnant goats were intermediate (Table 2). Increases in the rates of protein turnover per unit $\mathrm{BW}^{0.75}$ in pregnancy and lactation are associated with higher rates of protein synthesis in the fetus and mammary gland relative to the whole body (Duée \& Girard, 1983). In pregnant goats, the amount of endogenous $\mathrm{S}$ transferred to duodenal digesta increased by $1770 \mathrm{mg} / \mathrm{d}$ per unit increase in $\mathrm{BW}^{0.75}\left(\mathrm{~kg} \mathrm{BW}^{0.75}\right)$. This rate of increase was four times greater than in non-pregnant, non-lactating goats.

The composition of animal protein being synthesized influenced the extent of $S$ recycling to the gut. Fibre growth, including cashmere production, represented the principal form of $\mathrm{N}$ retention in non-pregnant, non-lactating goats, and was also evident in the pregnant and in the lactating goats used in the present study. The retention of each $1 \mathrm{~g} \mathrm{~N}$ was associated with an endogenous flow of $0.67 \mathrm{~g} \mathrm{~S} / \mathrm{d}$ at the duodenum when all goats were considered together. In lactating goats, the corresponding value was $1.55 \mathrm{~g} \mathrm{~S} / \mathrm{g} \mathrm{MN}$ secreted. The $\mathbf{S}: \mathrm{N}$ ratio in the milk secreted by our goats were five times lower than that in wood keratin (calculated from Tristam, 1953). This suggests that the secretion of S into the duodenum was limited by the availability of $\mathrm{S}$ amino acids in the body. Furthermore, the rate of turnover of those milk proteins relatively high in $\mathrm{S}$, the lactalbumins and lactoglobulins, may be considerably higher than that of total body protein, including hair. 
Table 6. Possible contributions of sulphur to duodenal digesta of non-pregnant, nonlactating goats in period $6^{*}$

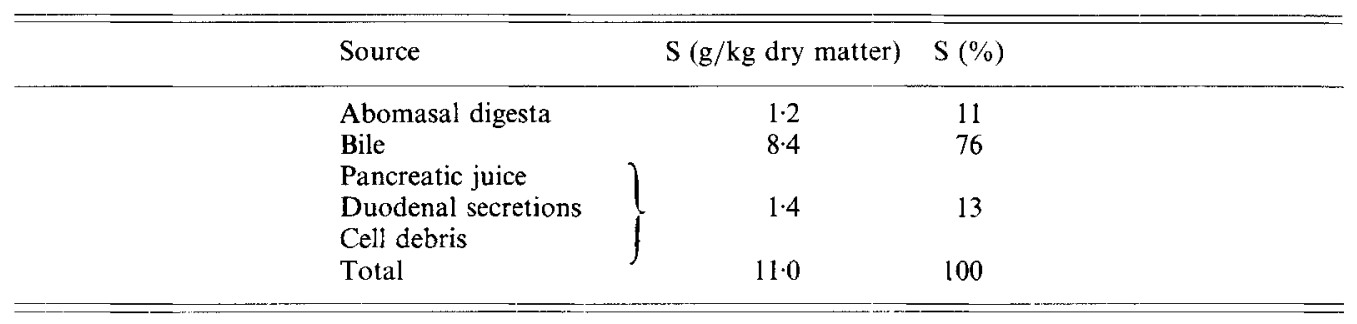

* For details, see p. 240.

$\mathrm{S}$ derived from the mobilization of body proteins may also have contributed to the enterohepatic circulation, particularly in lactating goats, with a mean loss of $0.4 \mathrm{~kg}$ body-weight per week. The $\mathrm{N}$ content of young eviscerated female goats, of Australian feral stock, was $26 \mathrm{~g} / \mathrm{kg}$ (Ash \& Norton, 1987). Assuming the same $\mathrm{N}$ content for tissues mobilized from the body of goats used in the present study and a N:S ratio of 15 for body proteins (Tristam, 1953), each $\mathrm{kg}$ loss in body-weight was associated with the mobilization of $1.7 \mathrm{~g} \mathrm{~S}$. Thus in lactating goats $\mathrm{S}$ mobilized from the body may have enhanced the enterohepatic circulation by up to $97 \mathrm{mg} / \mathrm{d}$, on average. There was, however, a considerable variation between goats in changes in body-weight during the monitoring periods, at all stages in the reproductive process. This may account for differences between goats in the extent of $S_{\text {GAIN }}$ per unit $N$ retained (NRM), as shown by the regression equation relating these two variables.

\section{Souces of $S$ in duodenal digesta}

The concentration of $S$ in digesta dry matter rose sevenfold between the abomasum and the duodenal cannula in those goats examined post-mortem. This rise was accompanied by an increase in the concentration of $\mathrm{N}$ in duodenal digesta (Fig. 1). The inputs of $\mathrm{S}$ at the duodenal cannula were estimated from the $\mathrm{S}, \mathrm{N}$ and dry matter contents of bile, and abomasal and duodenal digesta, using Pearson' square (Table 6). The enterohepatic circulation represented approximately $76 \%$ of the $\mathrm{S}$ transferred to duodenal digesta of nonpregnant, non-lactating goats, or on average $2.8 \mathrm{~g} \mathrm{~S} /$ goat per $\mathrm{d}$. The percentage may have been higher in lactating goats as indicated by an increase in the extent of ${ }^{35} \mathrm{~S}$ recycling in those animals.

The composition of endogenous $S$ in duodenal digesta

$\mathrm{nS}$ represented $99 \%$ of the $\mathrm{S}$ in duodenal digesta (Table 2); this is the $\mathrm{S}$ fraction resistant to acid hydrolysis by the method of Bird \& Fountain (1970), and attributed by these workers to $\mathrm{S}$ covalently linked to carbon. $\mathrm{nS}$ and $\mathrm{N}$ were secreted simultaneously into the gut as suggested by the relationship between the $\mathrm{S}$ and $\mathrm{N}$ transfers to duodenal digesta. Proteins from pancreatic and duodenal secretions and cell debris would have contributed to endogenous $\mathrm{S}$ and $\mathrm{N}$ flows into the gut. The minimum $\mathrm{N}: \mathrm{S}$ ratio of these proteins is 7.4 , the value for acetic-acid-precipitated material from secretions of the Brunner's glands of the duodenum of a goat (Florey \& Harding, 1934). However, the N:S ratio of duodenal digesta was $3 \cdot 0$ (Fig. 1), indicating that there must have been a substantial flow of nonprotein $\mathrm{S}$ into the gut. The $\mathrm{N}: \mathrm{S}$ ratio of bile from the gall bladder was 0.7 ; taurine, with a $N: S$ ratio of 0.44 by weight, is the most likely compound to have contributed to this flow. 


\section{Significance of an enterohepatic circulation of $S$}

The flow of endogenous $S$ into digesta of the goats in the present study occurred predominantly at the duodenum, but there are other sites for the transfer of $\mathbf{S}$ to the gut of ruminants. The relative importance of the various sites of transfer may alter with the demand for $\mathbf{S}$ for microbial protein synthesis in the gut. The faecal excretion of $\mathrm{S}$ was increased by up to $110 \mathrm{mg} / \mathrm{d}$ with infusions of glucose into the terminal ileum of sheep; urinary excretion decreased by similar amounts (Bird \& Thornton, 1972). These workers proposed that the transfer of $\mathrm{S}$ into fermentative areas of the gut was the pre-emptive pathway for its excretion in ruminants. In view of the relationship between biliary and urinary routes for the excretion of $\mathrm{nS}$ in our goats, the output of $\mathrm{S}$ in both bile and urine could be influenced by microbial activity in the gut. Our results show that a shift in the ratio $\mathrm{N}: \mathrm{S}$ transferred into duodenal digesta occurred in the course of reproduction-lactation (Table 2). A similar shift in response to changes in the uptake of endogenous $\mathrm{S}$ by gut microbes is entirely possible.

Hepatic conjugation with glycine, as an alternative to taurine, is a relatively modern evolutionary development most characteristic of herbivorous animals (Haslewood, 1962), and may represent an adaptation to a precarious dietary supply of S. Conversely, an enhanced retention of $S$, as taurine in bile, is likely when dietary intake of $S$ exceeds net uptake for animal protein synthesis. Thus, the enterohepatic circulation may act as a mobile reserve of $\mathrm{S}$, particularly of taurine.

\section{REFERENCES}

Amann, O. V. (1933). Le taux d'excrétion du soufre neutre constitue-t-il une charactéristique individuelle ou une constante de l'espèce? (The rate of neutral S excretion: is it an individual characteristic or a species constant?). Archives Internationales de Physiologie 37, 138-149.

Ash, A. J. \& Norton, B. W. (1987). Studies with the Australian Cashmere Goat. II. Effects of dietary protein concentration and feeding level on body composition of male and female goats. Australian Journal of Agricultural Research 38, 971-982.

Association of Official Analytical Chemists (1980). Official Methods of Analysis, 13th ed., pp. 7-30 [W. Horowitz, editor]. Washington, DC: Association of Official Analytical Chemists.

Bird, P. R. \& Fountain, R. D. (1970). A method for determination of sulphur in some biological materials. Analyst 95, 98-102.

Bird, P. R. \& Thornton, R. F. (1972). Sulphur metabolism and excretion studies in ruminants. XI. Cycling of ${ }^{35} \mathrm{~S}$ to the caecum and colon and the influence of the hindgut on sulphur excretion. Australian Journal of Biological Sciences 25, 1299-1311.

Bray, A. C. (1969). Sulphur metabolism in sheep. III. The movement of blood inorganic sulphate across the rumen wall of sheep. Australian Journal of Agricultural Research 20, 749-758.

Brody, S., Procter, R. C. \& Ashworth, U. S. (1934). Growth and development. XXXIV. Basal metabolism, endogenous nitrogen, creatinine and neutral sulphur excretions as functions of bodyweight. University of Missouri, College of Agriculture, Agricultural Experiment Station, Research Bulletin no. 220. Columbia, Missouri: University of Missouri.

Duée, P. H. \& Girard, J. (1983). Le métabolisme protéique pendant la gestation et la lactation (Protein metabolism in pregnancy and lactation). Procès-verbaux du IV Symposium International Métabolisme et Nutrition Azotés, Clermont-Ferrand, France, vol. 1, pp. 138-158. Paris: Institut National de la Recherche Agronomique.

Faichney, G. J. (1975). The use of markers to partition digestion within the gastrointestinal tract of ruminants. In Digestion and Metabolism in the Ruminant, pp. 277-293 [I. W. McDonald and A. C. I. Warner, editors]. Armidale, Australia: University of New England Publishing Unit.

Florey, H. W. \& Harding, H. E. (1934). Further observations on the secretion of Brunner's glands. Journal of Pathology and Bacteriology 39, 255-276.

Folin, O. (1905). A theory of protein metabolism. American Journal of Physiology 13, 116-138

Haslewood, G. A. D. (1962). Bile salts: structure, distribution and possible biological significance as a species character. In Comparative Biochemistry, vol. 3, pp. 205-229 [M. Florkin and H. S. Mason, editors]. New York: Academic Press.

Kennedy, P. M. \& Milligan, L. P. (1978). Quantitative aspects of transformation of sulphur in sheep. British Journal of Nutrition $39,65-84$. 
Reed, B. (1973). The determination of sulphur in plant material by X-ray fluorescence spectroscopy. Journal of the Science of Food and Agriculture 24, 139-146.

Reeds, P. J. \& Lobley, G. E. (1980). Protein synthesis: are there real species differences? Proceedings of the Nutrition Society 39, 43-52.

Sobotka, H. (1937). Physiological Chemistry of Bile, pp. 18-50. Baltimore: Williams and Wilkins.

Sokal, R. R. \& Rohlf, F. J. (1981 a). Biometry, 2nd ed., pp. 454-560. San Francisco: W. H. Freeman and Co.

Sokal, R. R. \& Rohlf, F. J. (1981 b). Biometry, 2nd ed., pp. 128-178. San Francisco: W. H. Freeman and Co.

Tristam, G. R. (1953). The amino acid composition of proteins. In The Proteins, vol. 1, part A, pp. 181-233 [H. Neurath and K. Bailey, editors]. New York: Academic Press. 